\title{
Commercial and Therapeutic Potential of Plant-Based Fatty Acids
}

\author{
Ana Paula de Souza e Silva, Wanessa Almeida da Costa, \\ Marielba de Los Angeles Rodriguez Salazar, \\ Priscila do Nascimento Bezerra, Flávia Cristina Seabra Pires, \\ Maria Caroline Rodrigues Ferreira, \\ Eduardo Gama Ortiz Menezes, Glides Rafael Olivo Urbina, \\ Jhonatas Rodrigues Barbosa and Raul Nunes de Carvalho
}

\begin{abstract}
This chapter reviews plant-based fatty acids as well as their methods of production, applications in the industry, and benefits in treatments of cardiovascular and cerebral diseases, besides being a source of food. The fatty acids obtained from vegetable matrices have been acting as alternatives to the use of lipids of animal origin, due to their limitation in relation to the increase in demand. Thus, plants have been investigated in order to act as sources of fatty acids and assist in the supply of such demands. Vegetable oils represent not only an economical alternative but also a beneficial source of human health.
\end{abstract}

Keywords: fatty acids, plants, nutraceuticals, cardiovascular diseases, brain functions

\section{Introduction}

Lipid components, especially fatty acids, are present in the most diverse forms of life, playing important roles in the structure of cell membranes and metabolic processes. In humans, omega-series fatty acids are required to maintain cell membranes, brain functions, and the transmission of nerve impulses under normal conditions. These fatty acids also play a key role in the processes of transfer of atmospheric oxygen to blood plasma, hemoglobin synthesis, and cell division. They are called essential because the human body does not synthesize them [1].

Fatty acids are classified according to the presence of double bonds between the carbon chains. They are called saturated fatty acids (SFA) if there are no double bonds; monounsaturated fatty acids (MUFA) if there is one double bond; and polyunsaturated fatty acids (PUFA) if two or more double bonds are present. Regarding the size of the carbon chain, PUFAs have number of carbons $\geq 16$ and are also called long-chain polyunsaturated fatty acids, whereas those with number of carbons $\geq 20$ are referred 
to as very long-chain polyunsaturated fatty acids. The PUFAs omega- 3 and omega- 6 are distinguished by their beneficial effects on human health, including their role in the synthesis of tissues [2].

Among the organisms that produce fatty acids, fish is the most consumed worldwide. However, its production has not been sufficient to supply the demand of the world market. Due to this fact, sources from agriculture have been replaced by fish oil. Moreover, nowadays, nutritionists also recommend the ingestion of vegetable oils as an important part of a healthy diet $[3,4]$.

The production of vegetable oils has advantages over the production of fish oil, since the methods of obtaining and purification of vegetable oils are simpler, resulting in cheaper processes [5].

\section{Plants as sources of fatty acids}

Fatty acids are present in both animal and plant species. Among the animal species, fish are the main sources of fatty acids, but there are a number of limitations regarding the use of fish oil as a supply of fatty acids. Among them, problems caused by harmful contaminants such as carcinogenic, teratogenic, mutagenic, and noncarcinogenic agents (antibiotics and heavy metals, for example) are highlighted. Other limitations on the production and commercialization of fish oil are also widely discussed, such as oil stability problems and unpleasant taste and odor, which result in higher production costs and create difficulties in the oil purification [6-10].

\begin{tabular}{|c|c|c|c|c|c|}
\hline \multirow[t]{2}{*}{ Species } & \multicolumn{4}{|c|}{ Fatty acid composition (\%) } & \multirow[t]{2}{*}{ Reference } \\
\hline & C16:0 & C18:1 & C18:2 & C18:3 & \\
\hline \multicolumn{6}{|l|}{ Nuts and seeds } \\
\hline $\begin{array}{l}\text { Arachis } \\
\text { hypogaea L. }\end{array}$ & $16.02 \pm 0.01$ & $53.80 \pm 0.01$ & $25.10 \pm 0.10$ & - & {$[13]$} \\
\hline $\begin{array}{l}\text { Bertholletia } \\
\text { excelsa H.B.K. }\end{array}$ & $14.04 \pm 0.75$ & $34.55 \pm 1.85$ & $40.15 \pm 2.13$ & $0.09 \pm 0.05$ & {$[14]$} \\
\hline Camellia L. & $14.76 \pm 0.01$ & $22.71 \pm 0.03$ & $56.27 \pm 0.03$ & $0.33 \pm 0.01$ & {$[15]$} \\
\hline $\begin{array}{l}\text { Chenopodium } \\
\text { quinoa Wild. }\end{array}$ & $9.58 \pm 0.02$ & $25.84 \pm 0.06$ & $49.55 \pm 0.07$ & $8.51 \pm 0.02$ & {$[16]$} \\
\hline $\begin{array}{l}\text { Cucurbita } \\
\text { maxima }\end{array}$ & $12.05 \pm 0.73$ & $23.90 \pm 1.01$ & $57.33 \pm 0.41$ & $0.32 \pm 0.02$ & {$[17]$} \\
\hline $\begin{array}{l}\text { Dipteryx alata } \\
\text { vogel }\end{array}$ & $5.71 \pm 0.01$ & $53.35 \pm 0.01$ & $24.59 \pm 0.01$ & $4.12 \pm 0.01$ & {$[18]$} \\
\hline $\begin{array}{l}\text { Helianthus } \\
\text { annuus L. }\end{array}$ & $6.70 \pm 0.30$ & $25.60 \pm 3.0$ & $65.80 \pm 2.90$ & $0.07 \pm 0.02$ & {$[19]$} \\
\hline $\begin{array}{l}\text { Heliophila } \\
\text { africana }\end{array}$ & $7.60 \pm 1.00$ & $23.4 \pm 2.20$ & $22.00 \pm 4.3$ & $4.2 \pm 0.60$ & {$[20]$} \\
\hline Lupinus albus & $6.30 \pm 0.30$ & $56.10 \pm 0.30$ & $18.40 \pm 0.40$ & $7.80 \pm 0.10$ & {$[21]$} \\
\hline $\begin{array}{l}\text { Myristica } \\
\text { fragrans }\end{array}$ & $17.53 \pm 0.01$ & $59.44 \pm 0.03$ & $13.83 \pm 0.02$ & $1.94 \pm 0.01$ & {$[22]$} \\
\hline $\begin{array}{l}\text { Moringa oleifera } \\
\text { Lam. }\end{array}$ & $23.65 \pm 0.68$ & $5.92 \pm 0.02$ & $6.84 \pm 0.05$ & - & {$[23]$} \\
\hline $\begin{array}{l}\text { Vaccinium } \\
\text { myrtillus } \mathrm{L} \text {. }\end{array}$ & $6.10 \pm 0.10$ & $23.30 \pm 0.00$ & $33.70 \pm 0.20$ & $35.50 \pm 0.00$ & {$[24]$} \\
\hline Zea mays $\mathrm{L}$. & $12.57 \pm 0.01$ & $29.70 \pm 0.11$ & $52.68 \pm 1.44$ & $1.12 \pm 0.01$ & {$[25]$} \\
\hline
\end{tabular}




\begin{tabular}{|c|c|c|c|c|c|}
\hline \multirow[t]{2}{*}{ Species } & \multicolumn{4}{|c|}{ Fatty acid composition (\%) } & \multirow[t]{2}{*}{ Reference } \\
\hline & C16:0 & C18:1 & C18:2 & C18:3 & \\
\hline \multicolumn{6}{|c|}{ Leaves, stems, roots and palms } \\
\hline Cassia tora $\mathrm{L}$. & $18.6 \pm 0.08$ & $11.2 \pm 0.04$ & $13.2 \pm 0.06$ & $16.1 \pm 0.02$ & {$[26]$} \\
\hline $\begin{array}{l}\text { Elaeis guineensis } \\
\text { Jacq. }\end{array}$ & $36.30 \pm 3.40$ & $47.40 \pm 2.50$ & $9.40 \pm 2.10$ & $0.50 \pm 0.30$ & {$[27]$} \\
\hline Morus alba & $26.38 \pm 0.01$ & $2.86 \pm 0.01$ & $14.76 \pm 0.91$ & $34.97 \pm 1.84$ & {$[28]$} \\
\hline Olea europaea L. & $20.30 \pm 0.80$ & $29.20 \pm 1.70$ & $5.80 \pm 0.30$ & $32.30 \pm 0.50$ & [29] \\
\hline $\begin{array}{l}\text { Panax ginseng } \\
\text { Meyer }\end{array}$ & $2.22 \pm 0.01$ & $1.0 \pm 0.01$ & $6.58 \pm 0.01$ & $0.39 \pm 0.01$ & {$[30]$} \\
\hline $\begin{array}{l}\text { Stevia } \\
\text { rebaudiana } \\
\text { (Bertoni) }\end{array}$ & $12.57 \pm 0.01$ & - & $33.14 \pm 0.01$ & - & [31] \\
\hline \multicolumn{6}{|l|}{ Fruits } \\
\hline $\begin{array}{l}\text { Caryocar } \\
\text { brasiliense }\end{array}$ & $31.90 \pm 0.10$ & $61.40 \pm 0.30$ & $2.30 \pm 0.10$ & $0.40 \pm 0.00$ & [32] \\
\hline Euterpe oleracea & $23.47 \pm 0.01$ & $57.73 \pm 0.01$ & $15.54 \pm 0.01$ & - & [33] \\
\hline Morus nigra $\mathrm{L}$. & $11.93 \pm 1.30$ & $6.0 \pm 0.14$ & $75.85 \pm 1.82$ & $1.51 \pm 0.27$ & {$[34]$} \\
\hline
\end{tabular}

Table 1.

Content of the main plant-based fatty acids (\%).

Fish oil is a limited resource. In 2017, there was an increase in its world production compared to 2016, but it did not reach the market expectation for 2017, resulting in an increasing trend in the global price [4].

One way to minimize the problems caused by the limitations in fish oil production is to use alternative sources such as vegetable oils. Lipids found in plants present, in their composition, polyunsaturated fatty acids (PUFA), mainly omega-6 and omega- 3 , which are derived from linoleic acid and $\alpha$-linolenic acids, respectively. Both are synthesized by plants and not by animal tissues and are classified as essential for good health and disease prevention [11].

Over the years, lipids derived from plants have been gaining prominence in the biotechnology area, mainly for the development of products with pharmacological potential [12].

When evaluating a potential source of fatty acids, its sustainability and ability to meet any demand must be considered. The possibility of a scalable production based on agriculture, coupled with low costs and ease of production, highlights the potential of plants as sources of fatty acids for human diet. Table 1 presents some plant matrices evaluated as sources of fatty acids.

\section{Obtaining and commercial applications of fatty acids}

Fatty acids present many applications, due to their physical, biological, and alimentary properties. Regarding their obtaining, there is a great diversity of conventional and modern techniques [35]. According to [36], one of the most traditional methodologies for obtaining oils rich in fatty acids, which involve the use of organic solvents, is Soxhlet $[36,37]$. Another technique used is cold pressing, even though it is a millenarian technique [38]. More sophisticated procedures, such as ultrasoundassisted extraction, supercritical fluids extraction, and enzyme extraction are also used to obtain such oils [39]. 
The extraction of oils can be carried out by Soxhlet using different parameters and organic solvents [40]. The most used solvent in this methodology is petroleum ether, due to its high solvation capacity, inertness, and good stability with oils. Time, temperature, and number of cycles are parameters that directly influence the oil yield obtained in the process [41]. In the methodology of [42], the classic extraction protocol based on chloroform and methanol is used, and it is performed in two different steps: the first one with homogenization and filtration and the second one with washing of the filtrate obtained in the first step, in order to collect the clean oil [42].

The methodology of [37] is an adaptation of that performed by [43], developed due to the need of a faster and simpler process, maintaining its efficiency and reproducibility. According to the needs faced by researchers, several adaptations based on these methodologies have already been developed, most of them with the purpose of obtaining oil of different matrices, with use of less aggressive solvents [40, 43].

A technique of low environmental impact is the extraction by cold pressing, which in addition to being faster, when compared with other techniques, and of low cost, no solvent is used. However, it does not have the ability to completely remove the lipid fraction of the matrix, and due to the absence of selectivity, an extract with low degree of purity is obtained; that is, it contains a greater variety of compounds besides the fatty acids. This type of oil is widely used in food industries [44].

Among the most modern techniques, the extraction by supercritical fluid outstands, which does not use toxic organic solvents, is efficient in obtaining oils rich in fatty acids and is a process with high selectivity [44]. The most commonly used solvent is carbon dioxide, because it is nontoxic, inert, and has low critical properties. In this process, the solvent is pressurized until it becomes a fluid in the supercritical state, with characteristics of liquid and gas, and presents high solubilization and diffusion power, which is able to extract the lipid fraction [45]. The ultrasonic scanning, on the other hand, occurs through ultrasonic waves that create bubbles in the solvent used; these bubbles rupture near the cell walls causing their rupture, and consequently leading to the release of the lipid fraction [46].

In addition to these techniques, there is the microwave-assisted enzymatic extraction, in which some enzymes (cellulase, pectinase, and proteinase), due to their potential of oil release from within membranes, come into contact with the aqueous matrix and react under agitation and microwave resonance. It is a clean methodology because it does not use organic solvents, and it is possible to obtain results similar to the traditional techniques regarding the content of fatty acids [47].

With a wide range of methodologies for obtaining oils rich in fatty acids, which go beyond those mentioned in this chapter, it is possible to obtain oils of the most varied qualities for the most varied applications. The fatty acids are high-value compounds used in the food and pharmaceutical areas. They are marketed predominantly in the form of edible oils, supplements in the form of gelatinous tablets, intravenous emulsions, and in oil-based products of topical use.

Edible vegetable oils rich in fatty acids are products widely consumed worldwide, and also the main sources of omega-9 (oleic acid). Omega-9 is the most consumed fatty acid in America through its main marketed sources, such as olive oil, oleaginous fruits (almonds and nuts), grape seeds, canola, sesame, sunflower, soybean, coconut, and palm oils, among others. Most of these products are linked to a healthy lifestyle of their consumers [48].

However, the increased incidence of diseases related to the lack of a balanced diet and the presence of sedentary lifestyles is one of the main factors driving the global market for fatty acid supplements, which directly increases the demand for isolated omega supplements (3, 6, and omega-9), or their main plant sources. Such products are indicated as a source of lipids to meet the energetic needs of patients who require 
parenteral nutrition when oral or enteral feeding is impossible, insufficient, or contraindicated [49]. It is also indicated in the treatment of rheumatoid arthritis [50].

Omega-3 supplements are generally consumed in the form of gelatinous tablets due to their residual taste, caused by their high instability to oxidation, which causes the product to exhibit odor and taste of fish. One of its main plant sources is linseed oil. These products are indicated for the prevention/treatment of cardiovascular diseases; for the reduction of triglycerides rates, total cholesterol and arterial pressure, and also in neurological treatments, improving concentration, memory, motivation, and motor abilities, besides neutralizing the stress and preventing degenerative brain diseases $[51,52]$. They are also indicated during pregnancy, reducing the risk of postpartum depression and mood swings, as well as improving health after child's birth [53].

Omega-6 supplements are usually marketed as evening primrose oil (EPO), which is its most popular form, being indicated in the prevention/treatment of problems related to premenstrual syndrome, diabetes, cardiovascular diseases, inflammation, skin problems, and cancer, as well as assisting the attention deficit/ hyperactivity disorder, reducing arterial hypertension and osteoporosis [54]. On the other hand, omega-9 supplements are the most commercialized in the form of intravenous emulsion. They are mostly made from refined olive and soybean oils, and found in the market in tablet form. Omega-9 supplementation is indicated for the reduction of waist circumference, combating total and bad cholesterol (LDL), and increasing the good one (HDL). Also, it presents anti-inflammatory activity and is involved in the prevention of coronary diseases, cancer, and aging [55].

Another way of commercializing fatty acids is in topical products. These products are aimed at the dermoprotection, being found in the market in liquid form, and in bandages soaked in oil. Some are indicated for nail strengthening due to their antifungal character (for example, oils derived from melaleuca, clove, thyme, and rosehip), whereas others are indicated for the treatment of all types of skin lesions, such as pressure sores, and venous stasis ulcer. Because of their emollient and healing properties, they improve the skin barrier function and reduce the symptoms of inflammation in atopic dermatitis and psoriasis, diminishing the transepidermal water loss $[56,57]$.

These fatty acid-based products may contain one or both fatty acids plus other substances, such as vitamin A, E, and soy lecithin. They can also integrate mediumchain triglyceride formulations, linoleic and linolenic acids, mainly responsible for this therapeutic effect, since they are the main constituents of the epidermal water barrier layer. The medium-chain triglycerides present in such formulations contain predominantly caprylic, capric, caproic, and lauric acids, which can be used as a nutritional source, solvents, and product stabilizers. When present in topical products, these acids have the function of lubricating the skin and hair, making the skin more resistant to infections, protecting it from chemical and enzymatic agents, preventing dryness, and accelerating the cicatricial processes. In addition, they are free of side effects [58-60].

Therefore, the application of fatty acids in food and pharmaceutical areas is of fundamental importance, in order to promote the development of new natural products that offer numerous benefits to their consumers.

\section{Nutraceutical functions}

A new paradigm of food health is evolving, in which the positive aspects of diet are more emphasized. Therefore, consumers are looking for beneficial, complementary or alternative products, and the nutraceutical ones particularly stand out. Nutraceutical 
comes from the combination of the words "nutrition" and "pharmaceutical," which was coined in 1989 by Dr. Stephen Defelice. It is considered food or part of food, or any substance of both plant and animal origin, which has positive effects on the health, playing an important role in maintaining the normal physiological function that keeps humans healthy, including the prevention and/or treatment of diseases [61-64].

Some of the most common ways of classifying nutraceuticals can be based on food sources, mechanisms of action, chemical nature, etc. Food sources used as nutraceuticals can be categorized as dietary fiber, prebiotics, probiotics, PUFAs, antioxidant vitamins, polyphenols, and other different types of herbal foods. These nutraceutical products help fight diseases such as obesity, cardiovascular diseases, cancer, osteoporosis, arthritis, diabetes, cholesterol, among others [53, 61, 65].

Long-chain PUFAs are also called essential fatty acids because they are necessary for vital functions in humans, as well as being an important source of energy for most tissues. In this sense, PUFAs can be divided into two groups: omega- 3 and omega-6. The major omega-3 fatty acids are $\alpha$-linolenic acid (ALA), eicosapentaenoic acid (EPA), and docosahexaenoic acid (DHA). ALA is the precursor of EPA and DHA, and its main sources are linseed, soybeans, and canola. The omega- 6 fatty acids consist mainly of linoleic acid (LA), $\gamma$-linolenic acid (GLA), and arachidonic acid (ARA). LA occurs mainly in corn, soybean, and sunflower oils. Essential fatty acids should be consumed through diet, since humans do not possess the enzymes to produce them [64-66].

Recent studies show the importance of PUFAs as essential fatty acids, and their nutritional value in human health and disease prevention. Intake of PUFAs has been associated primarily with decreased risk of cardiovascular diseases and normal brain development [66-68]. They also present anti-inflammatory effects and contribute to the good functioning of vision. In the study carried out by [69], it was shown that among PUFAs, ALA can serve as a great anti-inflammatory agent of the ocular surface. Its anti-inflammatory effects are comparable to those of corticosteroids. ALA's inhibition of pro-inflammatory cytokines was associated with a significant reduction of $\mathrm{I}-\kappa \mathrm{B} \alpha$. According to [70], dietary supplementation with PUFAs is a promising therapeutic option for patients with rheumatoid arthritis, considered as a chronic disease, in which many inflammatory pathways contribute to structural damage, joint swelling, and systemic inflammation.

More recently, studies have shown the benefits of PUFAs in cancer prevention. According to [71], PUFAs exert inhibitory effects on the growth of colon cancer cells. Metabolites of PUFAs such as prostaglandins and leukotrienes play an important role in colon cancer. Also, they are reported in the treatment of diabetes mellitus [72], based on clinical intervention studies performed in diabetic patients. It corroborates that dietary supplementation with $0.42-5.2 \mathrm{~g}$ of PUFAs per day for 8 weeks might become an alternative treatment against type 2 diabetes mellitus.

PUFAs have also been attributed to anticoagulant, vasodilator, and antiaggregant activities $[66,67]$. Specifically, the biological activities of essential fatty acids (ALA and LA) influence on the functions and responsiveness of cell membranes, tissue metabolism, hormone signals, and others. The beneficial effects of PUFAs can be mediated by different mechanisms, including altering or regulating cell membrane structures, regulating intracellular signaling pathways, modulating gene transcription, and regulating the production of bioactive lipid mediators or production of eicosanoids (prostaglandins, leukotrienes, and thromboxanes) [68, 73].

\section{Studies on cardiovascular diseases}

Essential fatty acids are considered nutraceutical or functional foods, exhibiting cardioprotective effect, due to their anti-inflammatory, hypolipidemic, 
antiatherogenic, antiarrhythmic, and antithrombotic properties, being thus used as risk reducers of cardiovascular diseases [74, 75].

Cardiovascular diseases have been reported as the leading cause of death in the western countries. According to data obtained in 2017 by the World Health Organization, cardiovascular diseases cause approximately $31 \%$ of deaths worldwide, making it clear that prevention is important for reducing these numbers [76].

Currently, the number of deaths due to cardiovascular diseases is increasing, and this is an important reason to carry out studies in order to obtain products that can contribute to a healthier diet through the intake of substances beneficial to heart health, such as unsaturated fatty acids (omega series), as well as reduce the intake of saturated fatty acids [76-82].

Researchers have investigated the reduction of the risk of cardiovascular diseases by implementing a diet rich in PUFAs. These studies confirm the efficiency of the intake of these acids, demonstrating a positive effect on lipid metabolism, and also emphasizing that diets rich in SFAs promote cardiovascular damage, as well as an increase in hypercholesterolemia. Nutritionists recommend that intakes of SFAs are maintained by up to $10 \%$ relative to total energy, based on dietary guidelines for prevention of cardiovascular diseases [80, 82-84].

Limiting the intake of SFAs becomes an important measure for the prevention of cardiac ischemia, since healthy eating habits can affect the development of diseases and reduce the risk of their occurrence in the myocardium. Thus, daily intake of PUFAs such as omega- 3 and omega- 6 is important. Experimental tests were carried out with people with ischemic heart failure, and the beneficial effect of PUFAs consumption was verified by the reduction of cardiovascular risk factors such as reduction of the inflammatory process in myocardial tissue, and acceleration of the healing process of the myocardium fibrous tissue [78, 83-89].

Coronary heart disease relates to the development of atherosclerosis, characterized by chronic inflammation of the tunica intima of large and medium-sized arteries. Such inflammation is caused by the interaction between the smooth muscle of the arterial walls and the plasma lipids, or platelets, lipoproteins, endothelium and monocytes, causing narrowing of the coronary arteries. Thus, the maintenance of a diet rich in dietary lipids acts as a therapeutic alternative in the prevention and treatment of various cardiovascular diseases such as strokes and thrombosis [90-92].

\section{Effects on brain functions}

The importance of fatty acids of vegetable origin in neural development, aging, and neurodegeneration has been addressed in several studies. The brain is an organ rich in phospholipids, which make up about $25 \%$ of its dry weight [93]. Some of these fatty acids participate in the structure, biochemistry, physiology, and consequently of the cerebral function, being necessary to maintain, under normal conditions, the cellular membranes, increasing their fluidity and functionality. They also aid in the nerve impulses transmission, reinforcing the importance of the adequate consumption of these lipids to benefit patients with neurological diseases [94, 95].

The consumption of PFAs is related to the reduction, prevention, and nonpharmacological treatment of some neurological diseases [96, 97]. Some studies show how eating habits can affect the brain development by making a comparison between the "Mediterranean diet" and the "western diet," for example. Whereas the Mediterranean diet is rich in long-chain PFAs derived from the combination of fruits, vegetables, cereals, olive oil, and other foods, the western diet is characterized by an increase in the consumption of SFAs and transfats due to the introduction of highly processed foods $[98,99]$. Experimental data relate these dietary components 
to neurological, neurodegenerative, and psychiatric disorders, since diets with high cholesterol rates increase the risk of developing such diseases, whereas diets with low saturated-fat intake reduce the risk of dementia [100-102], confirming the important role of diet in pathological mechanisms related to the brain.

The hypothesis that diet-induced changes affect brain circulation may be linked to changes in brain structure $[103,104]$. The fatty acid content may affect the production and function of dopamine and serotonin [105], since omega-series fatty acids are fundamental for the maintenance of dopaminergic function in the brain, whereas irregularities of these fatty acids can interfere in the function of the dopaminergic receptors [104]. Healthy aging of humans on a regular diet was associated with neuroprotective properties, such as increased volume of the cortex's gray matter, higher total brain volume, and less white matter hyperintensities (lesions) [106], whereas high-energy transfat diets are associated with increased brain atrophy, and reduced total brain volume and numbers of neurons [107].

Adequate dietary intake of fatty acids or their precursors is also important during the perinatal period (before and after the baby's birth), since to ensure the normal development of the brain, newborns need more lipids than adults do. They are essential for fetal growth and development, and for neurological, behavioral, and learning functions [108-110]. Therefore, insufficient supplementation during early life may also aid in the development of diseases related to poor brain development, such as coordination disorder, dyspraxia (neurological motor dysfunction), and attention-deficit/hyperactivity disorder [109]. And the ingestion of fatty acids, mainly of the $\omega-3$ type, positively affects the functioning and development throughout life, increasing cognitive functionality, such as learning, memory, and attention $[110,111]$.

\section{Conclusion}

Vegetable oils rich in essential fatty acids have been consumed instead of animal oils due to their high potential of production scalability, and because the fish oil market has not been able to satisfactorily meet the current consumers' demands. Several commercial applications have been developed with wide acceptability, and studies aimed at treating cardiovascular diseases and improving brain functions have reached promising results. In this sense, the use of plants as sources of fatty acids presents itself as a potential alternative not only in the economic scope, but also for human health. 


\section{Author details}

Ana Paula de Souza e Silva, Wanessa Almeida da Costa, Marielba de Los Angeles Rodriguez Salazar, Priscila do Nascimento Bezerra, Flávia Cristina Seabra Pires, Maria Caroline Rodrigues Ferreira, Eduardo Gama Ortiz Menezes, Glides Rafael Olivo Urbina, Jhonatas Rodrigues Barbosa and Raul Nunes de Carvalho* Program of Post-Graduation Food Science and Technology (LABEX)/FEA (Faculty of Food Engineering), Federal University of Para (UFPA), Belém, Pará, Brazil

*Address all correspondence to: raulncj@ufpa.br

\section{IntechOpen}

(C) 2018 The Author(s). Licensee IntechOpen. This chapter is distributed under the terms of the Creative Commons Attribution License (http://creativecommons.org/licenses/ by/3.0), which permits unrestricted use, distribution, and reproduction in any medium, provided the original work is properly cited. (cc) BY 


\section{References}

[1] Saravanan P, Davidson NC, Schmidt EB, Calder PC. Cardiovascular effects of marine omega-3 fatty acids. Lancet. 2010;376:540-550. DOI: 10.1016/ S0140-6736(10)60445-X

[2] Youdim KA, Martin A, Joseph JA. Essential fatty acids and the brain: Possible health implications. International Journal of Developmental Neuroscience. 2000;18:383-399. DOI: 10.1016/S0736-5748(00)00013-7

[3] Gatlin DM, Barrows FT, Brown P, Dabrowski K, Gaylor TG, Hardy RW, et al. Expanding the utilization of sustainable plant products in aquafeeds: A review. Aquaculture Research. 2007;38: 551-579. DOI: 10.1111/j.1365-2109.200.01704.x

[4] FAO. Globefish-Analysis and Information on World Fish Trade. [Internet]. 2017. Available from: http:// www.fao.org/in-action/globefish/ market-reports/resource-detail/ en/c/1113356/ [Accessed: 31-07-2018]

[5] Dyer JM, Stymne S, Green AG, Carlsson AS. High-value oils from plants. The Plant Journal. 2008;54:640-655. DOI: 10.1111/j.1365-313X.2008.03430.x

[6] Sidhu KS. Health benefits and potential risks related to consumption of fish or fish oil. Regulatory Toxicology and Pharmacology. 2003;38:336-344

[7] Foran JA, Good DH, Carpenter DO, Hamilton MC, Knuyh BA, Schwager SJ. Quantitative analysis of the benefits and risks of consuming farmed and wild salmon. The Journal of Nutrition. 2005;135:2639-2643. DOI: 10.1093/ jn/135.11.2639

[8] Perveen Z, Ando H, Ueno A, Ito Y, Yamamoto Y, Yamada Y. Isolation and characterization of a novel thraustochytrid-like microorganism that efficiently produces docosahexaenoic acid. Biotechnology Letters. 2006;28:197-202. DOI: $10.1007 /$ s10529-005-5335-4

[9] Li D, Hu X. Fish and its multiple human health effects in times of threat to sustainability and affordability: Are there alternatives? Asia Pacific Journal of Clinical Nutrition. 2009;218:553-563

[10] Park S, Johnson MA. Awareness of fish advisories and mercury exposure in women of childbearing age. Nutrition Reviews. 2006;64:250-256

[11] Din JN, Newby DE, Flapan

AD. Omega-3 fatty acids and cardiovascular disease-fishing for a natural treatment. BMJ. 2004:328-330

[12] Afnan F, Jameel A, Al-Laith AA. Fatty acid composition of three medicinal plants from Bahrain: New potential sources of $y$-linolenic acid and dihomo-y-linolenic. Industrial Crops and Products. 2013;43:218-224. DOI: 10.1016/j.indcrop.2012.07.021

[13] Escobedo RM, Hernández-Luna P, Joaquín-Torres IC, Ortiz-Moreno A, Robles-Ramírez MC. Physicochemical properties and fatty acid profile of eight peanut varieties grown in Mexico. CyTA Journal of Food. 2015;13(2):300-304. DOI: 10.1080/19476337.2014.971345

[14] Santos OV, Corrêa NCF, Carvalho Junior RN, Costa CCEF, Lannes SCS. Yield, nutritional quality, and thermal-oxidative stability of Brazil nut oil (Bertolletia excelsa H.B.K) obtained by supercritical extraction. The Journal of Supercritical Fluids. 2013;111:499-504. DOI: 10.1016/j. jfoodeng.2013.01.013

[15] Wang X, Zeng Q, Verardo V, Contreras MM. Fatty acid and sterol composition of tea seed oils: Their comparison by the "FancyTiles" 
approach. Food Chemistry.

2017;233: 302-310. DOI: 10.1016/j.

foodchem.2017.04.110

[16] Tang Y, Li X, Chen PX, Zhang

$\mathrm{B}$, Hernandez $\mathrm{M}$, Zhang $\mathrm{H}$, et al.

Characterization of fatty acid,

carotenoid, tocopherol/tocotrienol compositions and antioxidant activities in seeds of three Chenopodium quinoa Willd. genotypes. Food Chemistry. 2014:174:502-508. DOI: 10.1016/j. foodchem.2014.11.040

[17] Jiao J, Li Z, Gai Q, Li X, Wei F, Fu $\mathrm{Y}$, et al. Microwave-assisted aqueous enzymatic extraction of oil from pumpkin seeds and evaluation of its physicochemical properties, fatty acid compositions and antioxidant activities. Food Chemistry. 2014;147:17-24. DOI: 10.1016/j.foodchem.2013.09.079

[18] Fetzer DL, Cruz PN, Hamerski F, Corazza ML. Extraction of baru (Dipteryx alata vogel) seed oil using compressed solvents technology. The Journal of Supercritical Fluids. 2018;137:23-33. DOI: 10.1016/j.supflu.2018.03.004

[19] Ayerdi GA, Berger M, Labalette F, Centis S, Daydé J, Calmon

A. Comparative analysis of fatty acids, tocopherols and phytosterols content in sunflower cultivars (Helianthus annuus) from a three-year multi-local study. International Journal of Experimental Botany. 2015;84:14-25

[20] Smith MA, Zhang H. Very-longchain fatty acid diversity in nine Heliophila seed oils. South African Journal of Botany. 2018;117:50-56. DOI: 10.1016/j.sajb.2018.04.019

[21] Curti AA, Curti RN, Bonini N, Ramón AN. Changes in the fatty acid composition in bitter Lupinus species depend on the debittering process. Food Chemistry. 2017;263:151-154. DOI: 10.1016/j.foodchem.2018.04.118

[22] Kozłowska M, Gruczyńska E, Ścibisz I, Rudzińska M. Fatty acids and sterols composition, and antioxidant activity of oils extracted from plant seeds. Food Chemistry. 2016;213:450-456. DOI: 10.1016/j. foodchem.2016.06.102

[23] Lee JH, Kim YG, Park JG, Lee J. Supercritical fluid extracts of Moringa oleifera and their unsaturated fatty acid components inhibit biofilm formation by Staphylococcus aureus. Food Control. 2017;80:74-82. DOI: 10.1016/j.foodcont 2017.04.035

[24] Gustinelli G, Eliasson L, Svelander C, Alminger M, Ahrné L. Supercritical $\mathrm{CO} 2$ extraction of bilberry (Vaccinium myrtillus L.) seed oil: Fatty acid composition and antioxidant activity. The Journal of Supercritical Fluids. 2018;135:91-97. DOI: 10.1016/j. supflu.2018.01.002

[25] Carrillo W, Carpio C, Morales D, Vilcacundo E, Álvarez M, Silva M. Content of fatty acids in corn (Zea mays L.) oil from ecuador. Asian Journal of Pharmaceutical and Clinical Research. 2017;10:150-153. DOI: 10.22159/ajpcr.2017.v10i8.18786

[26] Shukla S, Hegde S, Kumar A, Chaudhary G, Tewari SK, Upreti DK, et al. Fatty acid composition and antibacterial potential of Cassia tora (leaves and stem) collected from different geographic areas of India. Journal of Food and Drug Analysis. 2016. DOI: 10.1016/j.jfda.2016.12.010

[27] Ramli US, Embi MN, Omar O, Sambanthamurthi R. Biochemical studies and purification of oil palm (Elaeis guineensis Jacq.) $\beta$-Ketoacyl-acylcarrier-protein (ACP) Synthase (KAS) II enzyme. Journal of Oil Palm Research. 2012;24:1432-1441

[28] Radojković M, Zeković Z, Mašković P, Vidović S, Mandić A, Mišan A, et al. Biological activities and chemical composition of Morus leaves extracts obtained by maceration 
and supercritical fluid extraction. The Journal of Supercritical Fluids. 2016;117:50-58. DOI: 10.1016/j. supflu.2016.05.004

[29] Wazs JM, Galanty A, Argasinska JG, Czochara MT, Szewczyk A, Nunes $\mathrm{R}$, et al. Identification of predominant phytochemical compounds and cytotoxic activity of wild olive leaves (Olea europaea L. ssp. sylvestris) harvested in South Portugal. Chemistry \& Biodiversity. 2017;14:1-10. DOI: 10.1002/cbdv.201600331

[30] Chung IM, Kim JK, Yang JH, Lee JH, Park SK, Son NY, et al. Effects of soil type and organic fertilizers on fatty acids and vitamin $\mathrm{E}$ in Korean ginseng (Panax ginseng Meyer). Food Research International. 2017;102:265-273. DOI: 10.1016/j.foodres.2017.10.003

[31] Siddique AB, Rahman SMM, Hossain MA. Chemical composition of essential oil by different extraction methods and fatty acid analysis of the leaves of Stevia Rebaudiana Bertoni. Arabian Journal of Chemistry. 2012;9:S1185-S1189. DOI: 10.1016/j. arabjc.2012.01.004

[32] Johner JCF, Hatami T, Meireles MAA. Developing a supercritical fluid extraction method assisted by cold pressing for extraction of pequi (Caryocar brasiliense). The Journal of Supercritical Fluids. 2018;137:34-39. DOI: 10.1016/j.supflu.2018.03.005

[33] Batista CCR, Oliveira MS, Araújo ME, Rodrigues AMC, Botelho JRS, Filho APSS, et al. Supercritical $\mathrm{CO}_{2}$ extraction of acaí (Euterpe oleracea) berry oil: Global yield, fatty acids, allelopathic activities, and determination of phenolic and anthocyanins total compounds in the residual pulp. The Journal of Supercritical Fluids. 2016;107:364-369. DOI: 10.1016/j.supflu.2015.10.006

[34] Salcedo EMS, Sendra E, Barrachina AAC, Martínez JJ, Hernández F. Fatty acids composition of Spanish black (Morus nigra L.) and white (Morus alba L.) mulberries. Food Chemistry. 2016. DOI: 10.1016/j.foodchem.2015.06.008

[35] Yanping Y, Zhang N, Tao W, Cao $\mathrm{X}, \mathrm{He} \mathrm{Y}$. Fatty acids as phase change materials: A review. Renewable and Sustainable Energy Reviews. 2014;29:482-498. DOI: 10.1016/j. rser.2013.08.107

[36] Ramluckan K, Moodley KG, Bux F. An evaluation of the efficacy of using selected solvents for the extraction of lipids from algal biomass by the Soxhlet extraction method. Fuel. 2013;116:103108. DOI: 10.1016/j.fuel.2013.07.118

[37] Bligh EG, Dyer WJ. A rapid method of total lipid extraction and purification. Canadian Journal of Biochemistry and Physiology. 1959;37:917. DOI: 10.1139/y59-099

[38] Górnaś P, Siger A, Juhṇeviča K, Lācis G, Šnē E, Seglin D. Cold-pressed Japanese quince (Chaenomeles japonica (Thunb.) Lindl. ex Spach) seed oil as a rich source of $\alpha$-tocopherol, carotenoids and phenolics: A comparison of the composition and antioxidant activity with nine other plant oils. European Journal of Lipid Science and Technology. 2014;116:563-570. DOI: 10.1002/ejlt.201300425

[39] Penteado RD. Extração de óleo de sementes de laranja por métodos não convencionais: Estudo comparativo da extração por ultrassom e com fluido supercrítico [thesis]. São José do Rio Preto: UNESP; 2017

[40] Tesfaye B, Tefera T. Extraction of essential oil from neem seed by using Soxhlet extraction methods. International Journal of Advanced Engineering, Management and Science. 2017;3:646650. DOI: $10.24001 /$ ijaems.3.6.5

[41] Masime JO, Ogur E, Mbatia B, Aluoch AO, Otieno G. Optimization and 
thermodynamics of the extraction of yellow oleander seed oil using Soxhlet extractor. Optimization. 2017;2:43-50

[42] Folch J, Lees M, Sloane Stanley $\mathrm{GH}$. A simple method for the isolation and purification of total lipids from animal tissues. The Journal of Biological Chemistry. 1957;226:497-509

[43] Johner JC, Hatami T, Meireles MAA. Developing a supercritical fluid extraction method assisted by cold pressing for extraction of pequi (Caryocar brasiliense). The Journal of Supercritical Fluids. 2018, 2018;137:34-39. DOI: 10.1016/j. supflu.2018.03.005

[44] De Melo MMR, Silvestre AJD, Silva CM. Supercritical fluid extraction of vegetable matrices: Applications, trends and future perspectives of a convincing green technology. The Journal of Supercritical Fluids. 2014;92:115-176. DOI: 10.1016/j.supflu.2014.04.007

[45] Dos Santos RR, Moreira DM, Kunigami CN, Aranda DAG, Teixeira CMLL. Comparison between several methods of total lipid extraction from Chlorella vulgaris biomass. Ultrasonics Sonochemistry. 2015;22:95-99. DOI: 10.1016/j.ultsonch.2014.05.015

[46] Jiao J, Li ZG, Gai QY, Li XJ, Wei FY, Fu YJ, et al. Microwave-assisted aqueous enzymatic extraction of oil from pumpkin seeds and evaluation of its physicochemical properties, fatty acid compositions and antioxidant activities. Food Chemistry. 2014;147:17-24. DOI: 10.1016/j.foodchem.2013.09.079

[47] Vannice G, Rasmussen H. Position of the academy of nutrition and dietetics: Dietary fatty acids for healthy adults. Journal of the Academy of Nutrition and Dietetics. 2014;114:136153. DOI: 10.1016/j.jand.2013.11.001

[48] Christensen RD, Henry E, Wiedmeier SE, Burnett J, Lambert DK. Identifying patients, on the first day of life, at high-risk of developing parenteral nutrition-associated liver disease. Journal of Perinatology. 2007;27:284-290. DOI: 10.1038/sj.jp.7211686

[49] Leeb BF, Sautner J, Andel I, Rintelen B. Intravenous application of omega-3 fatty acids in patients with active rheumatoid arthritis. The ORA-1 trial. An open pilot study. Lipids. 2006;41:2934. DOI: $10.1007 / 11745-006-5066-x$

[50] Connor WE. Importance of n-3 fatty acids in health and disease. The American Journal of Clinical Nutrition. 2000;7:171S-175S. DOI: 10.1093/ ajcn/71.1.171S

[51] Haag M. Essential fatty acids and the brain. The Canadian Journal of Psychiatry. 2003;48:195-203. DOI: 10.1177/070674370304800308

[52] Al MDM, Van Houwelingen AC, Hornstra G. Long-chain polyunsaturated fatty acids, pregnancy, and pregnancy outcome. The American Journal of Clinical Nutrition. 2000;471:285S-291S. DOI: 10.1093/ ajen/71.1.285s

[53] Lottenberg Amp. Importance of the dietary fat on the prevention and control of metabolic disturbances and cardiovascular disease. Arquivos Brasileiros de Endocrinologia e Metabologia. 2009;53:595-607. DOI: 10.1590/S0004-27302009000500012

[54] Mayser P, Grimm H, Grimminger F. $n-3$ fatty acids in psoriasis. British Journal of Nutrition. 2002;87:S77-S82. DOI: 10.1079/BJN2001459

[55] Lin MH, Khnykin D. Fatty acid transporters in skin development, function and disease. Biochimica et Biophysica Acta (BBA)—Molecular and Cell Biology of Lipids. 2014;1841:362-368. DOI: 10.1016/j. bbalip.2013.09.016 
[56] Magalhães MSF, Fechine FV, Macedo RN, Monteiro DLS, Oliveira CC, Brito GAC, et al. Effect of a combination of medium chain triglycerides, linoleic acid, soy lecithin and vitamins $\mathrm{A}$ and $\mathrm{E}$ on wound healing in rats. Acta Cirúrgica Brasileira. 2008;23:262-269. DOI: $10.1590 /$ S0102-86502008000300009

[57] Feingold Kr. The outer frontier: The importance of lipid metabolism in the skin. Journal of Lipid Research. 2009;50:S417-S422. DOI: 10.1194/jlr. R800039-JLR200

[58] Ferreira AM, De Souza BMV, Rigotti MA, Loureiro MRD. The use of fatty acids in wound care: An integrative review of the Brazilian literature. Revista da Escola de Enfermagem da USP. 2012;46:752-760. DOI: 10.1590/ S0080-62342012000300030

[59] Chauhan B, Kumar G, Kalam N, Ansari SH. Current concepts and prospects of herbal nutraceutical: A review. Journal of Advanced Pharmaceutical Technology \& Research. 2013;4:4-8. DOI: 10.4103/2231-4040.107494

[60] Aronson JK. Defining 'nutraceuticals': Neither nutritious nor pharmaceutical. British Journal of Clinical Pharmacology. 2017;83:8-19. DOI: 10.1111/bcp.12935

[61] Souyoul AS, Saussy KP, Lupo MP. Nutraceuticals: A review. Dermatolgic Therapy (Heidelb). 2018;8:5-16. DOI: 10.1007/ s13555-018-0221-x

[62] Das L, Bhaumik E, Raychaudhuri U, Chakraborty R. Role of nutraceuticals in human health. Journal of Food Science and Technology. 2012;49:173-183. DOI: 10.1007/s13197-011-0269-4

[63] Yadav V, Sharma L, Thomas B, Al HM. An overview on nutraceuticals as pharmacological agents. Advances in Bioresearch. 2012;3:113-128

[64] Abedi E, Sahari MA. Long-chain polyunsaturated fatty acid sources and evaluation of their nutritional and functional properties. Food Science \& Nutrition. 2014;2:443-463. DOI: 10.1002/fsn3.121

[65] Zárate R, Jaber-Vazdekis N, Tejera N, Pérez JA, Rodríguez C. Significance of long chain polyunsaturated fatty acids in human health. Clinical and Translational Medicine. 2017;6:25. DOI: 10.1186/s40169-017-0153-6

[66] Erdinest N, Shmueli O, Grossman Y, Ovadia H, Solomon A. Antiinflammatory effects of alpha linolenic acid on human corneal epithelial cells. Investigative Ophthalmology \& Visual Science. 2012;53:4396-4406. DOI: 10.1167/iovs.12-9724

[67] Simopoulos AP. The importance of the ratio of omega-6/omega-3 essential fatty acids. Biomedicine $\&$ Pharmacotherapy. 2002;56:365-379. DOI: 10.1016/S0753-3322(02)00253-6

[68] Navarini L, Afeltra A, Afflitto GG, Margiotta DPE. Polyunsaturated fatty acids: Any role in rheumatoid arthritis? Lipids in Health and Disease. 2017;16:197. DOI: 10.1186/ s12944-017-0586-3

[69] Zhang C, Yu H, Ni X, Shen S, Das UM. Growth inhibitory effect of polyunsaturated fatty acids (pufas) on colon cancer cells via their growth inhibitory metabolites and fatty acid composition changes. PLoS One. 2015;10:e0123256. DOI: 10.1371/journal. pone. 0123256

[70] Coelho OGL, da Silva BP, Rocha DMUP, Lopes LL, Alfenas RCG. Polyunsaturated fatty acids and type 2 diabetes: Impact on the glycemic control mechanism. Food Science \& 
Nutrition. 2016;57:3614-3619. DOI: $10.1080 / 10408398.2015 .1130016$

[71] Kaur N, Chugh V, Gupta AK. Essential fatty acids as functional componentes of foods-A review. Journal of Food Science and Technology. 2014;51:2289-2303. DOI: 10.1007/s13197-012-067

[72] Mišurcová L, Vávra Ambrožová J, Samek D. Seaweed lipids as nutraceuticals. Advances in Food and Nutrition Research. 2011;64:339-355 [Google Scholar] [PubMed]

[73] Mobraten K, Haug TM, Kleiveland CR, Lea T. Omega-3 and omega-6 PUFAs induce the same GPR120mediated signaling events, but with different kinetics and intensity in Caco- 2 cells. Lipids in Health and Disease. 2013;12:101-107 [Google Scholar] [CrossRef] [PubMed]

[74] WHO. World Health Organization. Cardiovacular disease. Fact Sheet $\mathrm{n}^{\circ}$ 317; 2013 [acesso 28 de junho 2018]. Disponível em: http://www.who.int/ cardiovascular_diseases/en/

[75] Revoredo CMS, Araújo CGB, Silva DFS, Rocha JKD, Libânio JA, Santos ACA. Nutritional implications of trans fatty acids on people's health: A reflective analysis article. Journal of Nursing UFPE on line. 2017;11(2):731-735. DOI: 10.5205/ reuol. 10263-91568-1-RV. 1102201729

[76] Ooi EMM, Watts GF, TWK N, HPHR B. Review effect of dietary fatty acids on human lipoprotein metabolism: A comprehensive update. Nutrients. 2015;7:4416-4425

[77] Kondo K, Ishida T, Yasuda T, Nakajima H, Mori K, Tanaka N, et al. Trans-fatty acid promotes thrombus formation in mice by aggravating antithrombogenic endotelial functions via Toll-like receptors. Wiley Online Library. 2015;59:729-740. DOI: 10.1002/ mnfr.201400537
[78] Raposo, H.F.; Efeito dos ácidos graxos n-3 e n-6 na expressão de genes do metabolismo de lipídeos e risco de arterosclerose. Revista de Nutrição, 23(5):871-879, set./out., 2010.

[79] Yunes JFF, Terra NN, Cavalheiro CP, Fries LLM, Godoy HT, Ballus CA. Perfil de ácidos graxos e teor de colesterol de mortadela elaborada com óleos vegetais. Ciência Rural. 2013;43(5):924-929

[80] Farnazzi-Machado FMV, Barbalho SM, Goulart R, Pessan Junior O. Use of cereal bars with quinoa (Chenopodium quinoa W.) to reduce risk factors related to cardiovascular diseases. Ciência e Tecnologia de Alimentos. 2012;32(2):239-244

[81] Mozaffarian D, Benjamin EJ, Go AS, et al. American Heart Association Statistics Committee and Stroke Statistics Subcommittee. Heart disease and stroke statistics--2015 update: A report from the American Heart Association. Circulation. 2015;131:e29-e322. DOI: 10.1161/ CIR.0000000000000152. pmid: 25520374

[82] Astrup A, Dyerberg J, Elwood $\mathrm{P}$, et al. The role of reducing intakes of saturated fat in the prevention of cardiovascular disease: Where does the evidence stand in 2010? The American Journal of Clinical Nutrition. 2011;93:684-688. DOI: 10.3945/ ajcn.110.004622. pmid: 21270379

[83] Santos RD, Gagliardi ACM, Xavier HT, Casella Filho A, Araújo DB, Cesena FY, et al. Sociedade Brasileira de Cardiologia. I Diretriz Brasileira de Hipercolesterolemia Familiar (HF). Arquivos Brasileiros de Cardiologia. 2012;99(2, supl. 2):1-28

[84] Lopes LL, Peluzio MCG, Hermsdorff HHM. Ingestão de ácidos graxos monoinsaturados e metabolismo lipídico. Jornal Vascular Brasileiro. 2016;15(1):52-60. DOI: 10.1590/1677-5449.008515 
[85] Rezaei SS, Litschauer B, Gouya G, Baumgartner-Parzer S, Stulnig T, Wolzt M. Cardiovascular effects of stress during acutely increased free fatty acids in a randomized, double-blind, crossover study in humans. Hormone and Metabolic Research. 2018;50(06):478484. DOI: $10.1055 / a-0620-8438$

[86] Stupin A, Rasic L, Matic A, Stupin M, Kralik Z, Kralik G, et al. Omega-3 polyunsaturated fatty acids enriched hen eggs consuption enhances microvascular reactivity in youn healthy individuals. Applied Physiology, Nutrition and Metabolism. 2018. DOI: 10.1139/apnm-2017-0735

[87] Oikonomou E, Vogiatzi G, Karlis D, Siasos G, Chrysohoou C, Zografos T, et al. Effects of omega-3 polyunsaturated fatty acids on fibrosis, endothelial function and myocardial performance, in ischemic heart failure patients. Clinical Nutrition. 2018. DOI: 10.1016/j.cinu.2018.04.017-2017-0735

[88] Kris-Etherton PM, Harris WS, Appel LJ. Fish consumption, fish oil, omega-3 fatty acids, and cardiovascular disease. Circulation. 2002;106:27472757 [Google Scholar] [CrossRef] [PubMed]

[89] Kris-Etherton PM, Grieger JA, Etherton TD. Dietary reference intakes for DHA and EPA. Prostaglandins, Leukotrienes and Essential Fatty Acids. 2009;81:99-104 [Google Scholar] [CrossRef] [PubMed]

[90] Maehre HK, Malde MK, Eilertsen KE, Elvevoll EO. Characterization of protein, lipid and mineral contents in common Norwegian seaweeds and evaluation of their potential as food and feed. Journal of the Science of Food and Agriculture. 2014;94:3281-3290 [Google Scholar] [CrossRef] [PubMed]

[91] Belanger M, Allaman I, Magistretti PJ. Brain energy metabolism: Focus on astrocyteneuron metabolic cooperation.
Cell Metabolism. 2011;14:724-738. DOI: 10.1016/j.cmet.2011.08.016

[92] Scorza FA, Cysneiros RM, Arida RM, Terra-Bustamante VC, de Albuquerque M, Cavalheiro EA. The other side of the coin: Beneficiary effect of omega-3 fatty acids in sudden unexpected death in epilepsy. Epilepsy \& Behavior. 2008;13:279-283. DOI: 10.1016/j.yebeh.2008.04.011

[93] Luchtman DW, Song C. Cognitive enhancement by omega3 fatty acids from child-hood to old age: Findings from animal and clinical studies. Neuropharmacology. 2013;64:550-565. DOI: 10.1016/j. neuropharm.2012.07.019

[94] Cunnane SC, Chouinard-Watkins R, Castellano CA, Barberger-Gateau P. Docosahexaenoic acid homeostasis, brain aging and Alzheimer's disease: Can we reconcile the evidence? Prostaglandins, Leukotrienes, and Essential Fatty Acids. 2013;88:61-70. DOI: 10.1016/j.plefa.2012.04.006

[95] Gadgil MD, Appel LJ, Yeung E, Anderson CA, Sacks FM, Miller ER. The effects of carbohydrate, unsaturated fat, and protein intake on measures of insulin sensitivity: Results from the OmniHeart trial. Diabetes Care. 2013;36:1132-1137. DOI: $10.2337 / \mathrm{dc} 12-0869$

[96] Anderson AL, Harris TB, Tylavsky FA, et al. Health ABC Study. Dietary patterns and survival of older adults. Journal of the American Dietetic Association. 2011;111:84-91. DOI: 10.1016/j.jada.2010.10.012

[97] Ornish D, Lin J, Chan JM, et al. Effect of comprehensive lifestyle changes on telomerase activity and telomere length in men with biopsyproven low-risk prostate cancer: 5-year follow-up of a descriptive pilot study. The Lancet Oncology. 2013;14(11):1112-1120. DOI: 10.1016/ S1470-2045(13)70366-8 
[98] Edwards LM, Murray AJ, Holloway CJ, Carter EE, Kemp GJ, Codreanu I, et al. Short-term consumption of a highfat diet impairs whole-body efficiency and cognitive function in sedentary men. FASEB Journal. 2011;25:10881096. DOI: $10.1096 /$ fj.10-171983

[99] Marin C, Yubero-Serrano EM, Lopez-Miranda J, Perez-Jimenez F. Endothelial aging associated with oxidative stress can be modulated by a healthy mediterranean diet. International Journal of Molecular Sciences. 2013;14:8869-8889. DOI: 10.3390/ijms14058869

[100] Boccardi V, Paolisso G, Mecocci P. Nutrition and lifestyle in healthy aging: The telomerase challenge. Aging (Albany NY). 2016;8:12-15. DOI: 10.18632/aging.100886

[101] Bowman GL, Silbert LC, Howieson D, Dodge HH, Traber MG, Frei B, et al. Nutrient biomarker patterns, cognitive function, and MRI measures of brain aging. Neurology. 2012;78:241-249. DOI: 10.1212/WNL.0b013e3182436598

[102] Chen JJ, Rosas HD, Salat DH. The relationship between cortical blood flow and sub-cortical white-matter health across the adult age span. PLoS One. 2013;8:56-73. DOI: 10.1371/journal. pone. 0056733

[103] Jiang L-H, Liang Q-Y, Shi Y. Pure docosahexaenoic acid can improve depression behaviors and affect HPA axis in mice. European Review for Medical and Pharmacological Sciences. 2012;16:1765-1773

[104] Tan ZS, Harris WS, Beiser AS, $\mathrm{Au}$ R, Himali JJ, Debette S, et al. Red blood cell omega3 fatty acid levels and markers of accelerated brain aging. Neurology. 2012;8:658-664. DOI: 10.1212/WNL.0b013e318249f6a9

[105] Holloway CJ, Cochlin LE, Emmanuel Y, Murray A, Codreanu I, Edwards LM, et al. A high-fat diet impairs cardiac highenergy phosphate metabolism and cognitive function in healthy human subjects. The American Journal of Clinical Nutrition. 2011;93:748-755. DOI: 10.3945/ ajcn.110.002758

[106] Kanoski SE, Davidson TL. Western diet consumption and cognitive impairment: Links to hippocampal dysfunction and obesity. Physiology \& Behavior. 2011;103:59-68. DOI: 10.1016/j.physbeh.2010.12.003

[107] Francis H, Stevenson R. The longer-term impacts of Western diet on human cognition and the brain. Appetite. 2013;63:119-128. DOI: 10.1016/j.appet.2012.12.018

[108] Lauritzen L, Carlson SE. Maternal fatty acid status during pregnancy and lactation and relation to newborn and infant status. Maternal \& Child Nutrition. 2011;7:41-58. DOI: 10.1111/j.1740-8709.2011.00303.x

[109] McNamara RK, Able J, Jandacek R, Rider T, Tso P, Eliassen JC, et al. Docosahexaenoic acid supplementation increases prefrontal cortex activation during sustained attention in healthy boys: A placebo-controlled, doseranging, functional magnetic resonance imaging study. The American Journal of Clinical Nutrition. 2010;91:1060-1067. DOI: 10.3945/ajcn.2009.28549

[110] Scheltens P, Twisk JW, Blesa R, Scarpini E, von Arnim CA, Bongers A, et al. Efficacy of Souvenaid in mild Alzheimer's disease: Results from a randomized, controlled trial. Journal of Alzheimer's Disease. 2012;31:225-236.

DOI: 10.3233/JAD-2012-121189

[111] Witte AV, Kerti L, Hermannstadter HM, Fiebach JB, Schreiber SJ, Schuchardt JP, et al. Long-chain omega-3 fatty acids improve brain function and structure in older adults. Cerebral Cortex. 2013. DOI: 10.1093/ cercor/bht163 